PEMBELAJAR: Jurnal Ilmu Pendidikan, Keguruan, dan Pembelajaran

Volume 2 Nomor 1 April 2018 hal 7-11

e-ISSN: 2549-9114 dan p-ISSN: 2549-9203

(Received: Agustus-2017; Reviewed: September-2017; Published: April 2018)

\title{
Penerapan Bimbingan Kelompok Terhadap Pencapaian Tugas Pekerjaan Bimbingan Sosial Pada Siswa Di SMA Negeri 1 Barru
}

\author{
Arman Bin Anuar \\ Universitas Negeri Makassar, \\ Kampus Tidung Jl. Tamalate., Kota Makassar, Sulawesi Selatan \\ Corresponding e-mail: arman.anward3@gmail.com
}

\begin{abstract}
Abstrak: Permasalahan dalam skripsi ini adalah apakah ada pengaruh penerapan bimbingan kelompok terhadap pencapaian tugas pekerjaan bimbingan sosial pada remaja di SMA Negeri 1 Barru ? adapun tujuannya adalah untuk mengetahui pengaruh penerapan bimbingan kelompok terhadap pencapaian tugas pekerjaan bimbingan sosial remaja di SMA Negeri 1 Barru. Penelitian ini adalah penelitian kuantitatif, dengan populasi sebanyak 839 responden, sedangkan sampel adalah 84 responden diperoleh dengan teknik random sampling, adapun instrument pengumpulan data yang digunakan adalah teknik angket dan dokumen, sementara teknik analisis data menggunakan rumus presentase. Hasil penelitian menunjukan adanya garis regresi yang terbentuk adalah $\mathrm{y}=2.22+0,786 \mathrm{X}$ sementara untuk menguji adanya pengaruh yang signifikan atau tidak, maka penelitian ini melakukan uji $\mathrm{F}$ yang hasilnya adalah Fhitung 933,7994 sedangkan Ftabel adalah 3,96. Berdasarkan hasil penelitian maka dapat disimpulkan bahwa terdapat pengaruh yang signifikan antara penerapan bimbingan kelompok terhadap pencapaian tugas pekerjaan bimbingan sosial pada SMA Negeri 1 Barru.
\end{abstract}

Kata kunci: bimbingan kelompok, tugas pekerjaan bimbingan sosial.

Abstract: The problem in this thesis is whether there is influence of the implementation of group guidance to the achievement of social work guidance tasks in adolescents in SMA Negeri 1 Barru? As for the purpose is to know the influence of the implementation of group guidance on the achievement of the task of youth social counseling in SMA Negeri 1 Barru. This research is quantitative research, with population as many as 839 respondents, while the sample is 84 respondents obtained by random sampling technique, while the data collection instruments used are questionnaires and documents, while data analysis techniques using the formula percentage. The result of the research shows that the regression line formed is $\mathrm{y}=2.22+0.786 \mathrm{X}$ while to test the significant effect or not, this research is $\mathrm{F}$ test which the result is Fhitung 933,7994 while Ftabel is 3,96. Based on the results of the study it can be concluded that there is a significant influence between the implementation of group guidance on the achievement of social guidance work on SMA Negeri 1 Barru.

Keywords: group guidance, social guidance work.

C2017 -Pembelajar Universitas Negeri Makassar. Ini adalah artikel dengan akses terbuka dibawah licenci CC BY-NC-4.0 (https://creativecommons.org/licenses/by-nc/4.0/ ). 


\section{PENDAHULUAN}

Pada dasarnya manusia adalah makhluk sosial, kehadirannya ditentukan oleh makhluk lainnya. Dalam perkembangannya akhirnya manusia membentuk kelompok-kelompok komunitas untuk memperjelas identitas dirinya. Sehingga berkelompok menjadi bagian dari makhluk sosial itu sendiri. Dengan banyaknya masalah yang dimiliki makhluk modern saat ini, tampaknya bahwa identitas mengelompok menjadi pudar dan berubah menjadi identitas individu. Oleh karena itu, saat ini konsep dalam bimbingan dan konseling memasukkan proses bimbingan kelompok sebagai bentuk terapi atau layanan yang diharapkan dapat memberikan terapi yang baik pada orang mengikutinya.

Pada siswa bimbingan kelompok menjadi penting artinya untuk mengetahui siswa yang memiliki masalah yang sama. Dengan berkelompok masalah itu menjadi ringan dan mudah apabila diselesaikan secara berkelompok. Bimbingan kelompok dilakukan bilamana siswa yang dilayani lebih dari satu orang. Kelompok ini terdiri dari siswa yang memiliki permasalahan yang sama sehingga mereka bisa saling berbagi.

Bimbingan kelompok dapat terlaksana dengan berbagai cara, misalnya dibentuk kelompok kecil dalam rangka layanan konseling (konseling kelompok), dibentuk kelompok diskusi, diberikan bimbingan karier kepada siswa-siswi yang tergabung dalam satu kesatuan kelas. Bimbingan kelompok merupakan sarana untuk menunjang perkembangan optimal masing-masing siswa, yang diharapkan dapat mengambil manfaat dari pengalaman pendidikan ini bagi dirinya sendiri.

Jadi dapat disimpulkan bahwa kegiatan bimbingan kelompok merupakan salah satu layanan bimbingan dan konseling yang diberikan kepada sejumlah individu dalam bentuk kelompok dengan memanfaatkan dinamika kelompok untuk membahas topik tertentu dipimpin oleh pemimpin kelompok yang bertujuan menunjang pemahaman, pengembangan dan pertimbangan pengambilan keputusan/ tindakan individu.

Di sekolah, siswa sering disibukkan dengan masalah-masalah yang berkaitan dengan pergaulan sosial, misalanya masalah konformitas, pertemanan yang retak, geng-geng sekolah, pubertas remaja, dan sebagainya. Masalah-masalah ini adalah masalah-masalah pergaulan sosial di sekolah. Masalah pergaulan sosial inilah yang biasanya menjadi konten dari bimbingan sosial yang dilakukan pada siswa.

Termasuk di SMA Negeri 1 Barru, sebagai sekolah dengan jumlah siswa yang banyak, terdiri dari berbagai kelompok sosial/strata sosial, dapat dipastikan akan selalu terjadi problem sosial remaja di sana. Tahun 2014 menurut data guru bimbingan dan konseling, ada lima perkelahian akibat masalah saling ejek dan mengganggu, walaupun semuanya diselesaikan dengan damai, tetapi menjadi catatan bagi guru dan sekolah agar peritiwa ini tidak terulang lagi.

Oleh karena itu, masalah sosial ini menjadi tugas dari bimbingan sosial pada siswa yang diberikan oleh guru bimbingan dan konseling pada semua siswa di SMA Negeri 1 Barru. Di dalam bimbingan sosial inilah siswa diberikan informasi tentang konflik sosial remaja, serta cara penanggulangannya. Cara penanggulangan itu menjadi tugas bagi siswa, agar secara preventif saling menjaga sehingga tidak terjadi konflik sosial antar siswa baik di dalam maupun di luar sekolah.

Beberapa tugas-tugas bimbingan sosial yang diberikan pada siswa adalah menjaga hubungan pertemanan dan menghindari perpecahan, tidak membuat geng-geng atau kelompok-kelompok dalam sekolah kecuali kelompok belajar, karena biasanya kelompok seperti inilah yang memicu permasalahan sosial remaja di sekolah. Hal lain adalah membina kerukunan antar siswa dan siswa lainnya di sekolah lain dalam bentuk kerjasama dalam berbagai kegiatan.

Berdasarkan latar belakang tersebut maka peneliti hendak mengetahui lebih jauh tentang penerapan bimbingan kelompok dan tugas siswa pada bimbingan sosial dalam suatu karya tulis ilmiah dengan judul "Pengaruh Penerapan Bimbingan Kelompok terhadap Pencapaian Tugas Pekerjaan Bimbingan Sosial pada Remaja di SMA Negeri 1 Barru."

Menurut Datspak (2017), anak membawa kemampuan berbahasa yang ditandai dengan adanya beberapa tanda-tanda komunikasi pertama seperti mengoceh dan menangis. Dalam hal ini sesungguhnya anak menyampaikan beberapa pesan dan secara bertahap dapat memproduksi kata-kata. Hal ini terus akan berlangsung sampai anak berusia satu tahun. Selanjutnya pada proses lebih lanjut, anak akan mampu menggabungkan beberapa kata dengan cara yang luar biasa sehingga menghasilkan beberapa kalimat. Pada usia tiga 
tahun maka anak telah dapat berpartisipasi dalam percakapan, mengajukan pertanyaan dan menjawab pertanyaan. Hal inilah yang mengisyaratkan betapa bahwa dalam perkembangan anak, perkembangan bahasa sebagai bagian dari kehidupan anak harus terus dikembangkan secara optimal.

Untuk mengembangkan bahasa anak berbagai metode dapat dilakukan di lembaga pendidikan. Salah satu hal yang dapat dilakukan adalah bermain peran, baik dilakukan secara makro maupun secara mikro. Bermain peran adalah media yang tepat dalam mengajarkan anak karena dapat menawarkan suatu pembelajaran yang holistik bagi anak untuk memperoleh seperangkat pengalaman bahasa (Rodgers, S. and Evans, J., 2008).

Berbagai penelitian pun telah membuktikan bahwa melalui bermain peran maka proses belajar mengajar dapat ditingkatkan di berbagai tingkat pendidikan dengan meningkatkan motivasi dan partisipasi aktif anak (Ments, M. V., 1999). Manfaat bermain peran juga dikemukakan oleh Dick dan Carey (2001) yang menekankan bahwa bermain peran merupakan cara yang efektif untuk mengembangkan kemampuan bahasa lisan dan dapat digunakan sebagai alternatif untuk mengembangkan kemampuan bahasa anak yang dapat memungkinkan mereka dapat menjadi seorang yang memiliki kemampuan komunikasi yang memadai. Dalam permainan peran menurut Bradshaw, M. J. and Lowernstein, A. J. (2011) maka anak akan dapat belajar sambil melakukan sesuatu. Hal inilah yang akan meningkatkan nilai dan kepercayaan, keterampilan praktis seperti bernegosiasi, berdebat dan menyampaikan pendapat.

\section{METODE}

\subsection{Jenis Penelitian}

Pendekatan penelitian ini menggunakan pendekatan kuantitatif dengan jenis korelasi.

\subsection{Variabel Penelitian}

Penelitian ini menggunakan dua variabel yaitu tugas bimbingan kelompok dan pekerjaan bimbingan sosial

\subsection{Variabel Penelitian}

2.3.1 Bimbingan kelompok adalah layanan bimbingan dan konseling yang diberikan secara berkelompok untuk mengetahui dan memberikan pemecahan masalah klien.

2.3.2 Tugas pekerjaan bimbingan sosial adalah tugas-tugas yang diberikan dari bimbingan sosial berupa tugas yang berkaitan dengan interaksi sosial seperti siswa diminta untuk menjaga pertemanan dan menghindari perpecahan, siswa dilarang membentuk geng-geng atau kelompok-kelompok tidak produktif dan dapat menimbulkan fanatisme kelompok, misalnya kelompok antarsuku, agama, dan kepemilikan (motor yang sama, ekskul yang sama, dll.), kecuali kelompok belajar yang produktif di sekolah

\subsection{Sampel Penelitian}

Adapun yang akan diambil sebagai sampel dalam penelitian ini adalah siswa kelas X, XI, XII SMA Negeri 1 Barru dimana $10 \%$ dari siswa yaitu $10 \%$ x $839=83,9=84$, namun setelah dilakukan konversi nilai maka sampel penelitian ini adalah 82 siswa pada tahun ajaran 2014/2015. Teknik pengambilan sampel yang digunakan yaitu Simple Random Sampling

\subsection{Teknik Pengumpulan Data}

2.5.1 Angket bimbingan kelompok dan angket tugas pekerjaan bimbingan sosial dengan lima alternatif pilihan yaitu sangat setuju, setuju, ragu-ragu, tidak setuju, sangat tidak setuju.

2.5.2 Dokumentasi berupa foto, dan lembaranlembaran, manuskrip yang memiliki keterkaitan terhada penelitian ini

2.5.3 Wawancara dengan coordinator guru dan konseling SMA Negeri 1 Barru

\subsection{Teknik Analisis Data}

Data kedua variabel ini akan dianalisis dengan rumus regresi sederhana sebagai berikut:

$$
\hat{y}=a+b x
$$

(Danang Sunyoto,Uji Khi Kuadrat Regresi, 2010:29)

Keterangan:

$\hat{y}_{=}$Subjek variabel terikat yang diproyeksikan 
$\mathrm{X}=$ variabel bebas

$\mathrm{A}=$ nilai konstanta harga $\mathrm{Y}$ jika $\mathrm{X}=0$

$\mathrm{B}=$ Nilai arah sebagai penentu ramalan (prediksi) yang menunjukkan nilai peningkatan (+) atau nilai penurunan (-) variabel Y

\section{HASIL DAN PEMBAHASAN}

\subsection{Hasil Penelitian}

Pada hasil penelitian ini akan dikemukakan data-data penelitian yang telah didapatkan berdasarkan edaran angket pada 84 siswa sampel.

Data akan dianalisis dengan menggunakan regresi sedehana adapun pemeriksaan keberartian regresi dilakukan melalui pengujian hipotesis nol, bahwa koefisien regresi sama dengan nol (tidak berarti) melawan hipotesis tandingan bahwa koefisien arah regresi tidak sama dengan nol.

Pengujian koefisien regresi dapat dilakukan dengan memperhatikan langkahlangkah pengujian hipotesis berikut:

3.1.1. Menghitung rumus $b$ dengan rumus

$$
b=\frac{N \cdot\left(\sum X Y\right)-\sum X \sum Y}{. N \cdot \sum X^{2}-\left(\sum X\right)^{2}}
$$

3.1.2. Menghitung rumus a dengan rumus

$$
a=\frac{\sum Y-b \sum X}{. N .}=\bar{Y}-b \bar{X}
$$

3.1.3. Menghitung persamaan regresi sederhana

$$
\hat{y}=a+b x
$$

3.1.4. Menentuka rumusan hipotesis $\mathrm{H}_{0}$ dan $\mathrm{H}_{1}$ -

Ho : $\rho=0$ : Tidak ada pengaruh variabel $X$ terhadap variabel $Y$

$\mathrm{H} 1: \rho \neq 0$ : Ada pengaruh variabel $\mathrm{X}$ terhadap variabel $Y$.

3.1.5. Mementukan uji statistika yang sesuai. Uji statistika yang digunakan adalah uji $F$. Untuk menentukan nilai uji $F$ dapat mengikuti langkah-langkah berikut:

3.1.5.1. Menghitung jumlah kuadrat regresi (JK reg(a) dengan rumus

$$
J K_{r e g(a)}=\frac{\left(\sum Y\right)^{2}}{n}
$$

3.1.5.2. Menghitung jumlah kuadrat regresi $b \mid a$ (JK reg bla

$$
J K_{r e g(b / a)}=b \cdot\left(\sum X Y-\frac{\sum X \cdot \sum Y}{n}\right)
$$

3.1.5.3. Menghitung jumlah kuadrat residu ( $\left.\mathrm{JK}_{\text {res }}\right)$ dengan rumus

$$
J K_{r e s}=\sum Y^{2}-J K_{\operatorname{Re} g(b / a)}-J K_{\operatorname{Re} g(a)}
$$

3.1.5.4. Menghitung rata-rata jumlah kuadrat regresi a (RJK reg (a)) dengan rumus:

$$
R J K_{\text {reg }(a)}=J K_{\operatorname{Re} g(a)}
$$

3.1.5.5. Menghitung rata-rata jumlah kuadrat regresi b/a (RJK reg (a) dengan rumus:

$$
R J K_{r e g(b / a)}=J K_{\operatorname{Re} g(b / a)}
$$

3.1.5.6. Menghitung rata-rata jumlah kuadrat residu (RJK res) dengan rumus:

$$
R J K_{\text {res }}=\frac{J K_{\mathrm{Re} s}}{n-2}
$$

3.1.5.7. Menghitung $F$, dengan rumus:

$$
F=\frac{R J K_{\operatorname{Re} g(b / a)}}{R J K_{\operatorname{Re} s}}
$$

\subsection{Menentukan nilai kritis ( $\alpha$ ) atau nilai tabel $F$ pada derajat bebas dbreg $b / a=1$ dan dbres $=\mathbf{n}-\mathbf{2}$.}

Membandingkan nilai uji $\mathrm{F}$ dengan nilai tabel F, dengan kriteria uji, Apabila nilai hitung $\mathrm{F}$ lebih besar atau sama dengan $(\geq)$ nilai tabel F, maka H0 ditolak.

Dari data tersebut maka diketahui nilainilai sebagai berikut:

- jumlah $\mathrm{n}=84$

- Jumlah $\sum x=4550$

- Jumlah $\sum x=3763$ 
- Jumlah $\sum x^{2}=247636$

- Jumlah $\sum x^{2}=204755$

3.2.1. Menghitung rumus $b$ dengan rumus

$$
\begin{aligned}
b & =\frac{N \cdot\left(\sum X Y\right)-\sum X \sum Y}{. N \cdot \sum X^{2}-\left(\sum X\right)^{2}} \\
b & =\frac{84 \cdot(204755)-4550 \cdot 3763}{.84 \cdot 247636-20702500} \\
b & =\frac{17199420-17121650}{.20801424-20702500} \\
b & =\frac{77770}{98924} \\
b & =0,786
\end{aligned}
$$

3.2.2. Menghitung rumus a dengan rumus

$$
\begin{aligned}
& a=\frac{\sum Y-b \sum X}{. N .} \\
& a=\frac{3763-0.786 .4550}{.84} \\
& a=\frac{37633576.3}{.84} \\
& a=2.222619
\end{aligned}
$$

3.2.3. Menghitung persamaan regresi sederhana

$$
y=2.22+0.786 X
$$

Untuk menetukan uji statistika yang sesuai. Uji Statistika yang digunakan adalah uji $\mathrm{F}$ untuk menentukan nilai uji $\mathrm{F}$ dapat mengikuti langkahlangkah berikut:

3.2.3.1. Menghitung jumlah kuadran regresi (JK reg (a))

$$
\begin{aligned}
& J K_{\operatorname{mg}(a)}=\frac{\left(\sum Y\right)^{2}}{n} \\
& J K_{\operatorname{mg}(a)}=\frac{14160149}{84} \\
& J K_{\operatorname{rg}(a)}=168573.4 \mid
\end{aligned}
$$

3.2.3.2. Menghitung jumlah kuadrat regresi $b \mid a$ (JK reg bla

$$
\begin{aligned}
& J K_{r e g(b / a)}=b \cdot\left(\sum X Y-\frac{\sum X \cdot \sum Y}{n}\right) \\
& J K_{r e g(b / a)}=0,786 \cdot\left(204755-\frac{4550 \cdot 3763}{84}\right) \\
& J K_{r e g(b / a)}=0,786 \cdot(204755-203829,2) \\
& J K_{r e g(b / a)}=0,786 \cdot 925,8 \\
& J K_{r e g(b / a)}=727,6788
\end{aligned}
$$

3.2.3.3. Menghitung jumlah kuadrat residu ( $\left.\mathrm{JK}_{\text {res }}\right)$ dengan rumus:

$$
\begin{aligned}
& J K_{\text {res }}=\sum Y^{2}-J K_{\operatorname{Reg}(b / a)}-J K_{\operatorname{Reg}(a)} \\
& J K_{\text {res }}=169365-727.6788-168573.4 \\
& J K_{\text {res }}=63.9212
\end{aligned}
$$

3.2.3.4. Menghitug rata-rata jumlah kuadrat regresi a (RJK reg (a) dengan rumus :

$R J K_{\text {reg }(a)}=168573.4$

3.2.3.5. Menghitung rata-rata jumlah kuadrat regresi b/a (RJK reg (a) dengan rumus : $R J K_{\text {reg }(b / a)}=727.6788$

3.2.3.6. Menghitung rata-rata jumlah kuadrat residu ( $\left.\mathrm{RJK}_{\text {res }}\right)$ dengan rumus:

$$
\begin{aligned}
R J K_{\text {res }} & =\frac{63,9}{84-2} \\
R J K_{\text {res }} & =0.779268
\end{aligned}
$$

3.2.3.7. Menghitung $F_{\text {hitung, dengan rumus: }}$

$$
\begin{aligned}
& F_{\text {hitung }}=\frac{R J K_{\text {reg }}(b \mid a)}{R J K_{\text {res }}} \\
& F_{\text {hitung }}=\frac{727.6788}{0.779268} \\
& F_{\text {hitung }}=933.7994
\end{aligned}
$$

\subsection{Pembuktian Hipotesis}

Hipotesis dalam penelitian ini adalah "Ada pengaruh penerapan bimbingan kelompok terhadap pencapaian tugas pekerjaan bimbingan sosial pada siswa SMA Negeri I Barru." untuk menguji hipotesis ini, maka hipotesis dekriptif ini akan diubah menjadi hipotesis statistik dengan ketentuan sebagai berikut:

$\mathrm{Ha}=$ adalah hipotesis alternatif

Ho = adalah hipotesis nihil, pengujian statistik hanya menguji hipotesis nihil (Ho)

Karena hipotesis nihil merupakan pernyataan tentang parameter yang bertentangan dengan 
keyakinan peneliti, apabila dari pengujian diperoleh keputusan yang mendukung atau setuju dengan Ho maka dapat dikatakan Ho diterima.

3.3.1. Pada penelitian ini yang menjadi hipotesis statistik adalah:

$\mathrm{Ha}=$ ada pengaruh penerapan bimbingan kelompok terhadap pencapaian tugas pekerjaan bimbingan social pada siswa SMA Negeri 1 Barru.

Ho = Tidak ada pengaruh penerapan bimbingan kelompok terhadap pencapaian tugas pekerjaan bimbingan social pada siswa SMA Negeri 1 Barru

Jika $F_{\text {hitung }} \geq \mathrm{F}_{\text {tabel, }}$ maka tolak Ho artinya signifikan dan jika $F_{\text {hitung }} \leq F_{\text {tabel, }}$, maka terima Ho artinya signifikan $(\alpha)=0,05$

3.3.2. Menentukan nilai kritis $(\alpha)$ atau nilai table $F$ pada derajat bebas $\mathrm{db}_{\mathrm{reg} b / \mathrm{d}}$ dan $\mathrm{db}_{\mathrm{res}}=\mathrm{n}-2$

Mencari nilai $\mathrm{F}_{\text {tabel }}$ menggunakan table $\mathrm{F}$ dengan rumus:

$\mathrm{Ft}_{\mathrm{abel}}=\mathrm{F}((1-\alpha)(\mathrm{db} \operatorname{Reg}[\mathrm{b} / \mathrm{a}]),(\mathrm{db} \operatorname{Res})$

$=\mathrm{F}((1-00,5)(1,84-2))$

$=\mathrm{F}((0,95)(1,82)$

3.3.3. Ketentuan angka $1=$ pembilang dan angka 82 adalah penyebut (lihat lampiran nilai $\left.\mathrm{Ft}_{\mathrm{abel}}\right)$

$\mathrm{F}_{\text {tabel }}=3,96$ dan diketahui $\mathrm{F}_{\text {hitung }}=933,4892$

Jadi $F_{\text {hitung }}>$ dari $F_{\text {tabel, }}$ maka tolak Ho artinya signifikan

Hal ini berarti bahwa hipotesis dalam penelitian ini diterima karena hipotesis nihil ditolak. Dengan demikian, dapat dikatakan bahwa terdapat pengaruh yang signifikan antara penerapan bimbingan kelompok terhadap pencapaian tugas pekerjaan bimbingan sosial pada siswa SMA Negeri I Barru

\subsection{Pembahasan Peneltian}

Kegiatan bimbingan kelompok merupakan salah satu layanan bimbingan dan konseling yang diberikan kepada sejumlah individu dalam bentuk kelompok dengan memanfaatkan dinamika kelompok untuk membahas topik tertentu dipimpin oleh pemimpin kelompok yang bertujuan menunjang pemahaman, pengembangan dan pertimbangan pengambilan keputusan/ tindakan individu.

Di sekolah, siswa sering disibukkan dengan masalah-masalah yang berkaitan dengan pergaulan sosial, misalanya masalah koformitas, pertemanan yang retak, geng-geng sekolah, pubertas remaja, dan sebagainya. Masalahmasalah ini adalah masalah-masalah pergaulan sosial di sekolah. Masalah pergaulan sosial inilah yang biasanya menjadi konten dari bimbingan sosial yang dilakukan pada siswa.

Guru bimbingan dan konseling dapat memanfaatkan beberapa layanan untuk memediasi masalah-masalah sosial yang ada di sekolah, salah satu layanan adalah bimbingan kelompok. Bimbingan kelompok dilakukan secara berkelompok sehingga siswa akan belajar melakukan sosialisasi di dalamnya.

Bimbingan kelompok Secara khusus bertujuan untuk mendorong pengembangan perasaan, pikiran, persepsi, wawasan dan sikap yang menunjang perwujudan tingkah laku yang lebih efektif, yaitu peningkatan kemampuan berkomunikasi baik verbal maupun non verbal para siswa. Dengan demikian, sikap sosial siswa dapat diasah lewat bimbingan kelompok.

Guru bimbingan dan konseling dapat memberikan stimulasi berupa tugas-tuga bimbingan sosial berupa bagaimana berinteraksi dan berkomunikasi di tengah lingkungannya, bagaimana cara menghidari konflik antarsesama, bagaimana bersosialisasi dengan cara-cara yang baik. Tugas-tugas ini diharapkan dapat memberikan pengaruh yang baik terhadap siswa, sehingga siswa dapat membina hubungan sosialnya dalam lingkungan sekolah di sekitarnya.

Penelitian ini juga membuktikan bahwa apakah ada pengaruh penerapan bimbingan kelompok terhadap pencapaian tugas pekerjaan bimbingan sosial pada siswa SMA Negeri I Barru. Setelah melakukan penelitian dengan membagikan angket pada 84 siswa, maka garis regersi yang terbentuk adalah $\mathrm{y}=2.22+0,786 \mathrm{X}$ sementara untuk menguji adanya pengaruh yang signifikan atau tidak, maka penelitian ini melakukan uji $\mathrm{F}$ yang hasilnya adalah fhitung 933, 7994 sedangkan ftabel adalah 3,96 sehingga berdasarkan kriteria bahwa jika fhitung lebih besar daripada ftabel, maka Ho atau hipotesis nihil ditolak yang berarti bahwa terdapat pengaruh yang signifikan antara penerapan bimbingan kelompok terhadap pencapaian tugas pekerjaan bimbingan sosial pada siswa SMA Negeri I Barru.

\section{Simpulan dan Saran}

\subsection{Kesimpulan}

Berdasarkan hasil penelitian maka dapat disimpulkan bahwa terdapat pengaruh yang signifikan antara penerapan bimbingan kelompok terhadap pencapaian tugas pekerjaan 
bimbingan sosial pada siswa SMA Negeri I Barru. Hal ini dapat dilihat dari uji f yang dilakukan, dan diketahui bahwa nilai f yang hasilnya adalah $\mathrm{f}_{\text {hitung }} 933,7994$ sedangkan $\mathrm{f}_{\text {tabel }}$ adalah 3,96.

Saran dari penelitian ini adalah Guru bimbingan dan konseling dapat menjadikan hasil penelitian ini sebagai bahan untuk melakukan langkah-langkah layanan selanjutnya pada siswa di SMA Negeri 1 Barru kemudian hasil penelitian ini dapat menjadi referensi pada peneliti lainnya yang akan mengangkat tema yang sama

\section{Daftar Rujukan}

Achmad Juntika Nurihsan, 2011. Bimbingan dan Konseling dalam Berbagai Latar Kehidupan, Bandung: Refika Aditama.

Bambang Prasetyo dan Lina Mifathul Jannah, 2013. Metode Penelitian Kuantitatif, Jakarta: Raja Grafindo Persada.

Bimo Walgito, 2010. Psikologi kelompok, Yogyakarta: Andi.

Bimo Walgito, 2010. Bimbingan + Konseling (Studi \& Karier), Yogyakarta: Andi.

Danang Suyonto, 2010. Uji Khi Kuadrat dan Regresi, Yogyakarta: Graha Ilmu.
Fenti Hikmawati, 2011. Bimbingan Konseling, Jakarta: Raja Grafindo Persada.

Hadi Suyono, 2008. Pengantar Psikologi Sosial 1, Yogyakarta: Pro Media.

Sukardi, 2014. Metodologi Penelitian Pendidikan Kompetensi dan Praktiknya, Jakarta: Bumi Aksara.

Suharsimi Arikunto, 2013. Prosedur Penelitian suatu Pendekatan Praktik, Jakarta: Rineka Cipta.

Sugiyono, 2008. Metode Penelitian Pendidikan (Pendekatan Kualitaif, Kuantitatif, dan R\&D), Bandung: Alfabeta.

Tohirin, 2009. Bimbingan dan Konseling di Sekolah dan Madrasah (Berbasis Integrasi), Jakarta: Raja Grafindo Persada.

Wardati dan Muhammad Jauhar, 2011. Implementasi Bimbingan dan Konseling di Sekolah, Jakarta: Prestasi Pustaka Raya. 